\title{
Gender digital divide in Maya-speaking contexts of southern Mexico
}

Brecha digital de género en comunidades maya-hablantes en el sureste de México

Diferença de gênero digital em comunidades de língua maia no sudeste do

México

J. Gabriel Domínguez Castillo

Autonomous University of Yucatán, México

jg.dominguez@correo.uady.mx https://orcid.org/0000-0002-2897-913X

Valentín Alonso-Novelo

Autonomous University of Yucatán, México valentin.alonso@correo.uady.mx http://orcid.org/0000-0002-1970-6594

Sergio Humberto Quiñonez Pech Autonomous University of Yucatán, México sergio.quinonez@correo.uady.mx http://orcid.org/0000-0001-5220-9912 


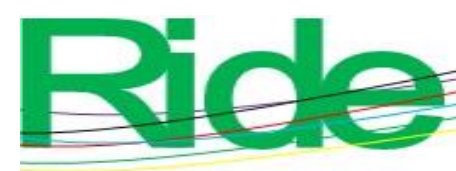

Revista Iberoamericana para la Investigación y el Desarrollo Educativo ISSN $2007-7467$

\section{Abstract}

The digital divide phenomenon arose in the early 90s due to internet popularization and telecommunications and information use management development. Numerous studies and authors agree that the basic premise of the digital divide is the difference that exists between individuals and societies that have access to computing, telecommunications and internet technology resources and those that do not (Schielfe 2008, Van Dijk \& Hacker 2003, Servon 2002, OECD 2001, Ginsburg, Sabatini \& Wagner 2000). The importance of information as a necessary element for society to function properly is where this phenomenon has its main emphasis, since those who do not have access to information, or have marginal contact with it, are excluded from a successful incorporation to social development.

This work analyses results of a study focused on gender differences in the use of technologies during a training program called: Reduction of the Digital Divide in Vulnerable and Young People of Vulnerable Communities (REBREDIG-PJA) of a southern Mayan-speaking area of Yucatan. This study's results are discussed concurring to Mexico's National Development Plan (2013-2018) and National Digital Strategy (2013) guidelines and compared with parameters stated in Yucatan State Development Plan (2012-2018).

Keywords: Digital divide, gender, technology, social development, training program

\section{Resumen}

El fenómeno conocido como Brecha digital (Digital Divide) surge en los albores de los 90s con la popularización del internet y el desarrollo de las telecomunicaciones en el manejo y utilización de la información. Diversos estudios y autores (Schielfe; 2008; Van Dijk \& Hacker 2003; Servon, 2002; OCDE, 2001; Ginsburg, Sabatini \& Wagner, 2000) coinciden en que la premisa básica de la brecha digital es la diferencia que existe entre individuos y sociedades que tienen acceso a los recursos tecnológicos de cómputo, telecomunicaciones e Internet y los que no. El énfasis mayor de este fenómeno se centra en la importancia que tiene la información como elemento indispensable, para que la sociedad funcione adecuadamente, ya que quien no tiene acceso a la información o la tiene de modo marginal, se ve excluido del desarrollo social y de la incorporación exitosa al curso del mismo.

En este estudio, se analizan las diferencias existentes por género para el uso de las tecnologías en el proceso de un programa formativo denominado: Reducción de la Brecha Digital en 


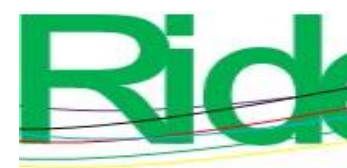

Revista Iberoamericana para la
Investigación y el Desarrollo Educativo
ISSN $2007-7467$

Personas Jóvenes y Adultas de Comunidades Vulnerables (REBREDIG-PJA) de una zona maya-hablante del sur de Yucatán. Los resultados de este estudio se discuten bajo los lineamientos del Plan Nacional de Desarrollo (2013-2018) y la Estrategia Digital Nacional, (2013) para México y se comparan con los lineamientos declarados en el Plan Estatal de Desarrollo (2012-2018) para Yucatán.

Palabras clave: Brecha digital, genero, tecnología, desarrollo social, programa formativo.

\section{Resumo}

O fenômeno conhecido como Digital Divide (Digital Divide) surge no início dos anos 90 com a popularização da internet e o desenvolvimento de telecomunicações no gerenciamento e uso da informação. Vários estudos e autores (Schielfe; 2008; Van Dijk \& Hacker 2003; Servon, 2002; OCDE, 2001; Ginsburg, Sabatini \& Wagner, 2000) concordam que a premissa básica da divisão digital é a diferença que existe entre indivíduos e sociedades que têm acesso a recursos tecnológicos para computação, telecomunicações e Internet e aqueles que não possuem. A ênfase principal desse fenômeno está centrada na importância da informação como elemento indispensável para que a sociedade funcione adequadamente, uma vez que aqueles que não têm acesso à informação ou a têm de maneira marginal são excluídos do desenvolvimento social e da sociedade. incorporação bem-sucedida no curso.

Neste estudo, analisamos as diferenças existentes por gênero no uso de tecnologias no processo de um programa de treinamento denominado: Redução da lacuna digital em jovens e adultos de comunidades vulneráveis (REBREDIG-PJA) de uma área de língua maia do sul de Yucatán. Os resultados deste estudo são discutidos sob as diretrizes do Plano Nacional de Desenvolvimento (2013-2018) e da Estratégia Nacional Digital (2013) para o México e são comparados com as diretrizes estabelecidas no Plano Estadual de Desenvolvimento (20122018) para Yucatan.

Palavras-chave: fosso digital, gênero, tecnologia, desenvolvimento social, programa de treinamento.

Fecha Recepción: Octubre 2019

Fecha Aceptación: Julio 2020 


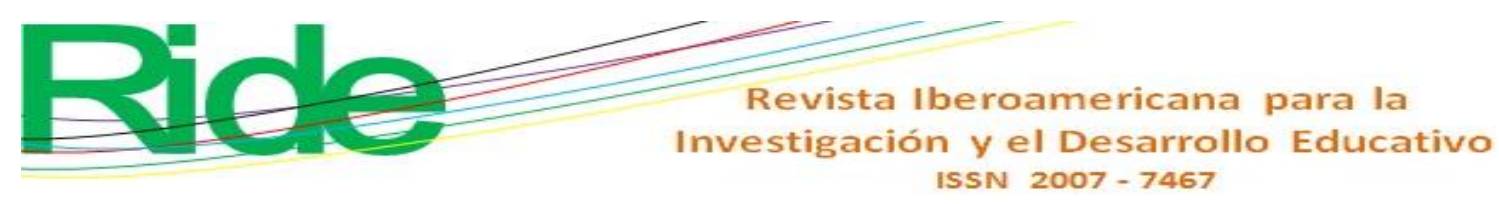

\section{Introduction}

In the dawn of the 1990's, the digital divide phenomenon arose because of Internet's popularization and telecommunications development on information use and administration (ICT). Several researchers (Lichy, 2011, Eynon, 2009, Schielfe, 2008, Livingstone \& Helsper, 2007, Van Dijk \& Hacker 2003, Cooper \& Weaver, 2003, Servon, 2002, OECD, 2001, Ginsburg, Sabatini \& Wagner, 2000) agree that digital divide's basic premise is the gap that computing, telecommunication and internet build between individuals and societies that have access to these resources and those who do not. Since information, the highlight of this phenomenon is an important and essential element to create connections helping society to work properly and fairly, therefore, those who do not have access to information, or have it in a marginal way, are excluded from a successful incorporation to social development. Globally, digital divide's impact has been the subject of numerous studies: Leaving no one Behind from digital divide to digital empowerment (UNESCO; 2017); Bridging the digital divide in the EU (Negreiro; 2015); Digital Dividends (The World Bank, 2016); Capturing Digital Dividends and Closing Digital Divides (OCDE, 2013); Bridging Gaps, Building Opportunity - Broadband as a Catalyst of Economic Growth and Social Progress in Latin America and the Caribbean (IDB, 2012). In Spain, for example, the 2016 Statistical Yearbook, issued by the National Institute of Statistics (INE) found that, according to the 2016 Survey on Equipment and Use of Information and Communication Technologies in homes, $18.1 \%$ of households in Spain do not have access to Internet (INE, 2016), showing that a significant percentage of Spanish houses are excluded from the digital universe. In terms of gender, there is a gap of $3.4 \%$ per person (pp), which means the percentage of male Internet users by 2014 were $77.9 \%$ and for women $74.5 \%$, results that may seem acceptable, but compared with Finland, Norway, New Zealand or Ireland, situation is far from expected internet access gender parity.

Castaño, Martín and Martínez (2011) outlined a composite indicators system to describe the gender digital divide through a study conducted in 31 European countries. This tool, called Gender and ICT Indicators System (SIGTIC), allows: a) to make inter-gender comparisons, determined by the degree of e-equality; b) perform intra-gender analysis, depending on the degree of e-inclusion of each sex; and c) contextualize the results obtained with those corresponding to 31 European countries. The outcomes show the presence of a gender digital divide, determined not only by e-access, but also by the level of e-inclusion, showing a clear 


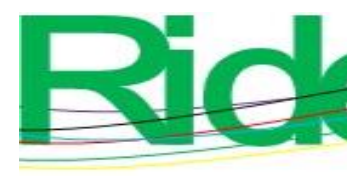

Revista Iberoamericana para la Investigación y el Desarrollo Educativo ISSN $2007-7467$

feminine disadvantage in the intensity of ICT use, additionally presents evidence of the use certain segments of internet according to gender: recreational and economic (masculine); of social welfare (feminine).

In the article The digital divide between Male and Female users in Internet Public Access Sites, Dixon, Correa, Straubhaar, Covarrubias, Graber and Spencer (2014), examine the evidence of the gender digital divide in public internet access points (community technology centres, libraries and others) in Austin, Texas. Using extensive observations of the participants, authors found that male users are the most numerous group in public access to internet use, even considering age and ethnicity. Similarly, in-depth interviews revealed that both sexes saw public access places, different form libraries, as the least desirable to use internet. In the case of libraries, the study revealed women associated them with books and family nostalgia, while men related them. Finally, elder users described technophobia feelings.

In this logic, USA's National Center for Women \& Information Technology (NCWIT, 2010) stated that $56 \%$ of the 2009 Advanced Placement exam applicants were women, but females only represented $18 \%$ of the people who took the exam in the Computer Science area (CS AP). In fact, since 1999, the Advanced Placement Program in Computer Science has systematically been the program with fewer women (NCWIT, 2010). NCWIT data is consistent with information found in countries such as Canada (Dionne-Simard, Galarneau \& Larochelle-Coté, 2016); Germany (Schinzel, 2017); United Kingdom (WISE, 2015); China (Powell \& Chang, 2016) and Romania (Ward, Dragne \& Lucas, 2014), all documenting in recent years a significant decrease in women's enrollment in study fields related to technology and engineering.

United Kingdom’s British Council (2016) carried out a study entitled: Gender equality and empowerment of women and girls in the $U K$, where this parliamentary committee mentions that, despite the great global impact of digital technology and «Big data» in public and consumer services, benefits are not shared equally, and technology is playing an important role in the emergence of new inequalities (gaps). As a developed country, the UK has almost achieved universal primary and secondary education. Girls enjoy greater educational achievements, but there are still some areas where results are not fair. There is a clear gender segregation in areas selected by young woman in secondary and postsecondary education, mainly in STEM (Science, Technology, Engineering and Mathematics) related ones. Due to 


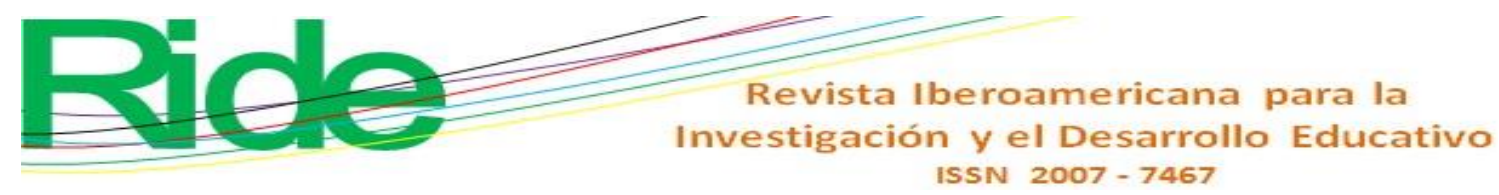

low participation in STEM in the UK, women represent only 15\% of ICT professionals (European average is 18\%) and less than $30 \%$ of the entire ICT workforce. These proportions are stagnant when analyzed and compared with the comportment of other developed countries. Similarly, the study shows that worldwide, the number of female technology directors has remained immobile for the last ten years.

In Albury, Australia, Atkinson, Black \& Curtis (2008) studied the digital divide in this region focusing on its existence, identifying strategies to address it, and developing a methodology to explore it in any context. Results showed the existence of digital divide, is linked to computer access differences in access and related to income level, city area of residency, age range and education. In general, the model indicates that individuals with lower levels of education and income and higher age range report a greater incidence of the digital divide. However, the authors, based on their research, mention ways to deal with the digital divide that could be applied to contexts where this phenomenon exists: training and technical support provision to the affected, improvement of access, approach to ICT services knowledge, as well as the procurement of appropriate hardware and software for disadvantaged groups.

The research: Digital Technologies and Gender Justice in India, Gurumurthy \& Chami (2014) mentions that the 2013 International Telecommunication Union measurement on information society places India in the «least Connected Countries» category, based on the composite media of ICT access, technology use skills and ICT use. Cited study defines less connected countries as those in which "... access and use of information and communication technologies are limited to basic voice and low-speed data services". This study also mentions, that in the Indian context, there is gender gap in ICT access, data concurs with information other studies and authors, who have found that $11.6 \%$ of male Indians are connected online while only 8.4\% of Indian women are (Anderson, 2015; World Economic Forum, 2013; Vigneswara, 2013), therefore, Intel (2013), appraised a 27\% weighted gender difference, meaning females in India are $27 \%$ less likely to have internet access than men. Added to that, researches by the GSMA Development Fund and the Cherie Blair Foundation have found that only $28 \%$ of Indian women have a mobile phone, compared to $40 \%$ of men (GSMA, 2010). 


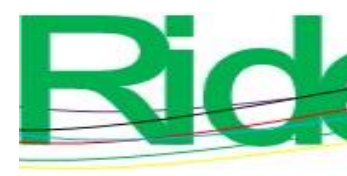

\section{Revista Iberoamericana para la Investigación y el Desarrollo Educativo ISSN 2007 - 7467}

In Mexico, Yucatan's Autonomous University (UADY) and Yucatan's state government education ministry (SEGEY), supported a study conducted by Dominguez, Canto, Ortega and McCalman (2016) study, with teachers from 19 high schools, 85\% belonging to an urban environment (Merida) and 15\% to rural settings located in towns such as Umán, Caucel and Acanceh. Main results showed teachers belonging to urban educational centers had better skills for ICT use, compared with those in rural environments. It was also observed that there is a digital divide between participants sex, since men registered better ICT use competencies in comparison with women.

Outcomes form previously reviewed intentional studies (Gurumurthy \& Chami, 2014; Castaño, Martín \& Martínez, 2011; Atkinson, Black \& Curtis, 2008 and Cooper, 2006) and those carried out in Maya-speaking contexts of south-eastern Mexico (Domínguez, Canto, Ortega \& McCalman, 2016), coincide this era is characterized by precipitous changes in Information and Communication Technologies (ICT) which affect the way society learns, works and relates, despite the fact that in developing countries a growing gap is emerging, a new form of division or exclusion, in which women seem to have disadvantages facing the benefits of technological evolution and information society, marginalizing them from employment, income and education opportunities of improvement in this digital age.

\section{Method}

Research's methodological development was mixed-type in an applied setting. Design was carried out under an action research focus, a scientific research method widely nowadays in several countries as Great Britain, Germany, USA, Spain, Canada, Australia, among others (Boggino \& Rosekrans, 2007 and Elliot, 2005). This work was part of a larger study aiming to reduce the digital divide between young people and adults (YP\&A) of vulnerable communities in southern Yucatan by strengthening their digital ICT use skills.

At the research-action stage a training programme called REBREDIG-PJA was implemented, lasting five months and integrated by thirteen units of competence. These units were gradually constructed and presented in complexity order from computer basic knowledge (how to connect, turn on / off, keys knowledge) to possible ICT consequences on health (postures, addictions, etcetera). It was meaningful the assistance received from three community advisers belonging to Yucatan's Adults Education Institute (IEAEY) and three experts from UADY's ICT area during the construction of the programme. 


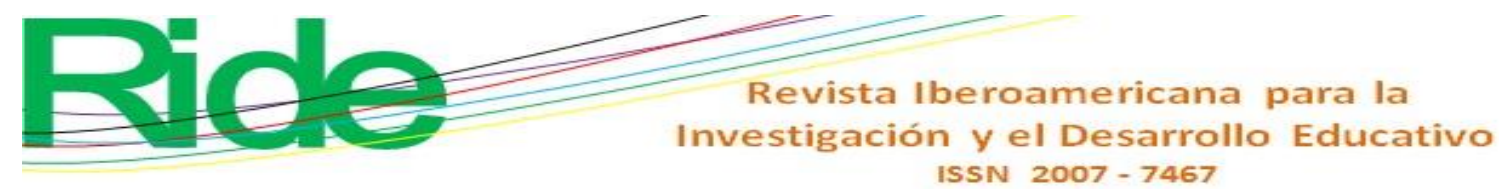

\section{Community characteristics}

According to Mexico's last population census raised in 2010 by the National Institute of Statistics and Geography (INEGI), Mayapan is one of the one hundred and six municipalities of Yucatan. By that time, INEGI (2010) reported 3,269 inhabitants, representing 0.2\% of the state's population, and for every 105 men there were 100 women, population median age was 19 years. Finally, for every 100 people at productive age (15 to 64 years) there are 80 at dependency age (under 15 or over 64 years).

Average number of live births by age group is very variable in this county; it ranges from 0.3 children born alive in women between 15 and 19 years up to 6.1 for women between 45 and 49 years.

Indicators related to ICT in this community are relevant and significant to this study. INEGI results showed that for every 100 homes only one had internet connection, which has serious social implications, widening the digital divide. On top of that, only $1.9 \%$ of the population has a computer, it is reasonable to think that of every 100 homes scarcely two homes have a computer. Furthermore, just 7.4\% have telephone service and 29\% mobile telephony.

Examining population's educational level, it is noticed that 588 inhabitants have no education, $78.8 \%$ of them have basic education, $2.4 \%$ have higher secondary education and only $0.6 \%$ (19 people) have higher education. Incidentally, we must not forget many authors (Dominguez, 2015; Atkinson, Black \& Curtis, 2008), have determined the absence of postsecondary education as one of the main factors that contributes to sharpen the digital divide phenomenon.

\section{Participants}

This research involved 119 YP\&A from Mayapan, participating in the second year of the project Reduction of the digital divide in vulnerable communities of Yucatan; 70 women (58.8\%) and 49 men (41.2\%). Partakers' ages ranged from 13 to 53 years being the average age 16 years. $98.5 \%$ of participants $98.5 \%$ are Maya-speakers. Table 1 presents results of main variables that best characterize participating population: 
Table 1. Population characterizing variables.

\begin{tabular}{|c|cc|c|cc|c|cc|c|cc|}
\hline $\begin{array}{c}\text { Maximum } \\
\text { studies } \\
\text { degree }\end{array}$ & $f$ & $\%$ & $\begin{array}{c}\text { Marital } \\
\text { status }\end{array}$ & $f$ & $\%$ & $\begin{array}{c}\text { Mother's } \\
\text { schooling } \\
\text { level }\end{array}$ & $f$ & $\%$ & $\begin{array}{c}\text { Father's } \\
\text { schooling } \\
\text { level }\end{array}$ & $f$ & $\%$ \\
\hline Elementary & 35 & 29.4 & Single & 98 & 82.4 & $\begin{array}{c}\text { No } \\
\text { schooling }\end{array}$ & 37 & 31 & $\begin{array}{c}\text { No } \\
\text { schooling }\end{array}$ & 23 & 19.3 \\
\hline $\begin{array}{c}\text { Middle } \\
\text { school }\end{array}$ & 80 & 67.2 & Married & 15 & 12.6 & Elementary & 63 & 53 & Elementary & 65 & 54.6 \\
\hline High school & 4 & 3.4 & $\begin{array}{c}\text { Consensual } \\
\text { union }\end{array}$ & 6 & 5 & $\begin{array}{c}\text { Middle } \\
\text { school }\end{array}$ & 19 & 16 & $\begin{array}{c}\text { Middle } \\
\text { school } \\
\text { High school }\end{array}$ & 29 & 24.4 \\
\hline Total & 119 & 100 & & 119 & 100 & & 119 & 100 & & 119 \\
\hline
\end{tabular}

Source: elaborated by the author with program data REBREDIG-PJA (2017)

As shown above, $67.2 \%$ of the participants (80) have middle school ( $7^{\text {th }}$ to $9^{\text {th }}$ grade), followed by $29.4 \%$ (35) with elementary level ( $1^{\text {st }}$ to $6^{\text {th }}$ grade) and only $4 \%$ have high school level $\left(10^{\text {th }}\right.$ to $12^{\text {th }}$ grade). Regarding marital status, the majority is single $(82.4 \%)$, followed by married subjects $(15 \%)$ and at last those who live in consensual union (6\%). Concerning the participants parents' education, mothers (women) without studies (37) are more than fathers (men) that are only 23. However, analysing parents academic training, both mothers $(53 \%)$ and fathers $(54.6 \%)$ prime study level is elementary. Overall, Table I shows important parents lack schooling, having women higher rates, in this type of Mayan-speaking communities.

\section{Instrument}

Instrument was constructed by Domínguez, Vázquez, Suaste \& Cab (2016), considering demographic and personal data relevant to the study, adopting a Likert-type measurement scale with one step and six levels, where YP\&A were asked to think about their competencies realization level (CCC), considering an ascending numerical scale from 0 to 5.

Table 2. Statement model and response format of each domain.

\begin{tabular}{|c|l|l|l|l|l|l|l|l|l|l|l|l|l|l|l|}
\hline \multirow{2}{*}{ Competences } & \multicolumn{9}{|c|}{ CCC } & \multicolumn{3}{c|}{ CICT } & \multicolumn{3}{c|}{ EIA } \\
\cline { 2 - 10 } & 0 & 1 & 2 & 3 & 4 & 5 & Yes & No & Yes & No \\
\hline DOM 1. COMPUTER KNOWLEDGE & \multicolumn{10}{|c|}{} \\
\hline I recognize computer's external components & 0 & 1 & 2 & 3 & 4 & 5 & Yes & No & Yes & No \\
\hline I turn on and turn off the computer properly & 0 & 1 & 2 & 3 & 4 & 5 & Yes & No & Yes & No \\
\hline
\end{tabular}

Source: Data retrieved from Domínguez, Vázquez, Suaste \& Cab (2016) 


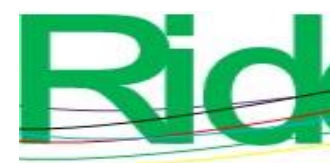

\section{Revista Iberoamericana para la Investigación y el Desarrollo Educativo ISSN 2007 - 7467}

Simultaneously, participants were queried to assess if the competence would be important to get a job (CICT) and if they would be interested in learning this competence (EIA), as shown in Table 2.

Thirteen competences composed the instrument and gave a diagnosis on those YP\&A had to strengthen. Table 3 presents domains that integrated the instrument, for better understanding purposes, emphasizing that each assessment was integrated by three sections (CCC, CICT, EIA) as mentioned previously.

Table 3. Instrument competences and technical indicators.

\begin{tabular}{|c|c|c|c|}
\hline Code & Domain name & Domain elements & $\alpha$ \\
\hline D1 & Computers knowledge & 7 & .760 \\
\hline D2 & Documents production & 7 & .760 \\
\hline D3 & Copyright knowledge & 4 & .595 \\
\hline D4 & Applications and programs & 3 & .517 \\
\hline D5 & Information localization & 4 & .609 \\
\hline D6 & Storage and retreating & 3 & .596 \\
\hline D7 & Communication & 4 & .510 \\
\hline D8 & Internet Interaction & 4 & .553 \\
\hline D9 & Personal data protection & 5 & .659 \\
\hline D10 & Safety & 6 & .759 \\
\hline D11 & Internet use risks & 5 & .620 \\
\hline D12 & Web interactions & 5 & .717 \\
\hline D13 & ICT health consequences & 5 & \\
\hline
\end{tabular}

Source: elaborated by the author with program data REBREDIG-PJA (2017)

Conceptual basis of Dominguez, Canto, Ortega \& McCalman (2016); Suárez, Almerich, Gargallo \& Aliaga (2010) works were taken as reference while constructing the three sections instrument: competences (CCC), importance for employment (CICT), and interest in learning competence (EIA) for collecting one-step primary data. First section integrated questions to be answered with a Lickert type six level rating scale (0 to 5) to denote the competitiveness degree of the digital competence. 
Table 4. Instrument section and technical indicators.

\begin{tabular}{|l|c|}
\hline \multicolumn{1}{|c|}{ Scale's sections } & Cronbach's Alpha \\
\hline Competence domain (CCC) & .979 \\
\hline Employment importance (CICT) & .985 \\
\hline Learning interest (EIA) & .959 \\
\hline Total & .960 \\
\hline
\end{tabular}

Source: elaborated by the author with program data REBREDIG-PJA (2017)

Using a dichotomist scale (yes / no), participants were directed to answer, how important the competence is to get a job; and finally, if they would be interested in learning it. Technical indicators for these sections are presented in Table 4.

\section{Results}

Table 5 presents descriptive statistics and scores (pre-test) obtained by men and women from Mayapan participating in the study, regarding their technology use skills prior the beginning of the training. In the table below, the results that have to observe the behavior of the participants' variables in each of the competencies analyzed in this study. 
Table 5. Gender domain comparison (pre-test).

\begin{tabular}{|c|c|c|c|c|c|c|c|}
\hline \multirow{2}{*}{\multicolumn{2}{|c|}{$\begin{array}{c}\text { Competences } \\
(* \mathrm{D}=\text { Competence code })\end{array}$}} & \multirow[b]{3}{*}{$\mathrm{N}$} & \multirow{2}{*}{\multicolumn{3}{|c|}{\begin{tabular}{c|c|} 
& Men \\
Pre-test
\end{tabular}}} & \multicolumn{2}{|c|}{ Women } \\
\hline & & & & & & Pre-t & \\
\hline$* \mathrm{D}$ & Domain name & & $\bar{x}$ & $D E$ & $\mathrm{~N}$ & $\bar{x}$ & $D E$ \\
\hline D1 & Computers knowledge & 49 & 2.32 & 1.03 & 70 & 1.63 & .887 \\
\hline D2 & Documents production & 49 & 2.01 & 1.12 & 70 & 1.44 & .954 \\
\hline D3 & Copyright knowledge & 49 & 1.56 & 1.09 & 70 & 1.07 & .912 \\
\hline D4 & Applications and programs & 49 & 1.95 & 1.26 & 70 & 1.43 & 1.14 \\
\hline D5 & Information localization & 49 & 2.01 & 1.17 & 70 & 1.57 & 1.13 \\
\hline D6 & Storage and retreating & 49 & 2.23 & 1.37 & 70 & 1.62 & 1.26 \\
\hline D7 & Communication & 49 & 2.24 & 1.26 & 70 & 2.26 & 1.19 \\
\hline D8 & Internet Interaction & 49 & 2.05 & 1.44 & 70 & 1.72 & 1.21 \\
\hline D9 & Personal data protection & 49 & 1.76 & 1.34 & 70 & 1.50 & 1.24 \\
\hline D10 & Safety & 49 & 1.98 & 1.48 & 70 & 1.39 & 1.12 \\
\hline D11 & Internet use risks & 49 & 1.66 & 1.27 & 70 & 1.70 & 1.16 \\
\hline D12 & Web interactions & 49 & 2.18 & 1.53 & 70 & 2.17 & 1.28 \\
\hline D13 & ICT health consequences & 49 & 1.86 & 1.42 & 70 & 1.49 & 1.29 \\
\hline
\end{tabular}

Source: elaborated by the author with data from REBREDIG-PJA outcomes (2017)

Results show that, at the training program beginning, men obtained higher scores than women in 11 of the 13 competences. In the Communications competence women got higher scores $(\mathrm{x}=2.26)$ than men $(\mathrm{x}=2.24)$. This competence relates to: sending and receiving SMS messages on the cell phone; exchanging information by email; chat through tools like Whatsapp and participate in social networks like Facebook, Instagram, amongst others. Women also obtained higher scores on internet use risks $(\mathrm{x}=1.70)$ than men $(\mathrm{x}=1.66)$.

\section{Pre-test competence level by age}

Aiming to contrast the 13 digital competences at pre-test stage, Figure 1 presents results by project's YP\&A participants groped by age. 
Figure 1. Age group competences contrast.

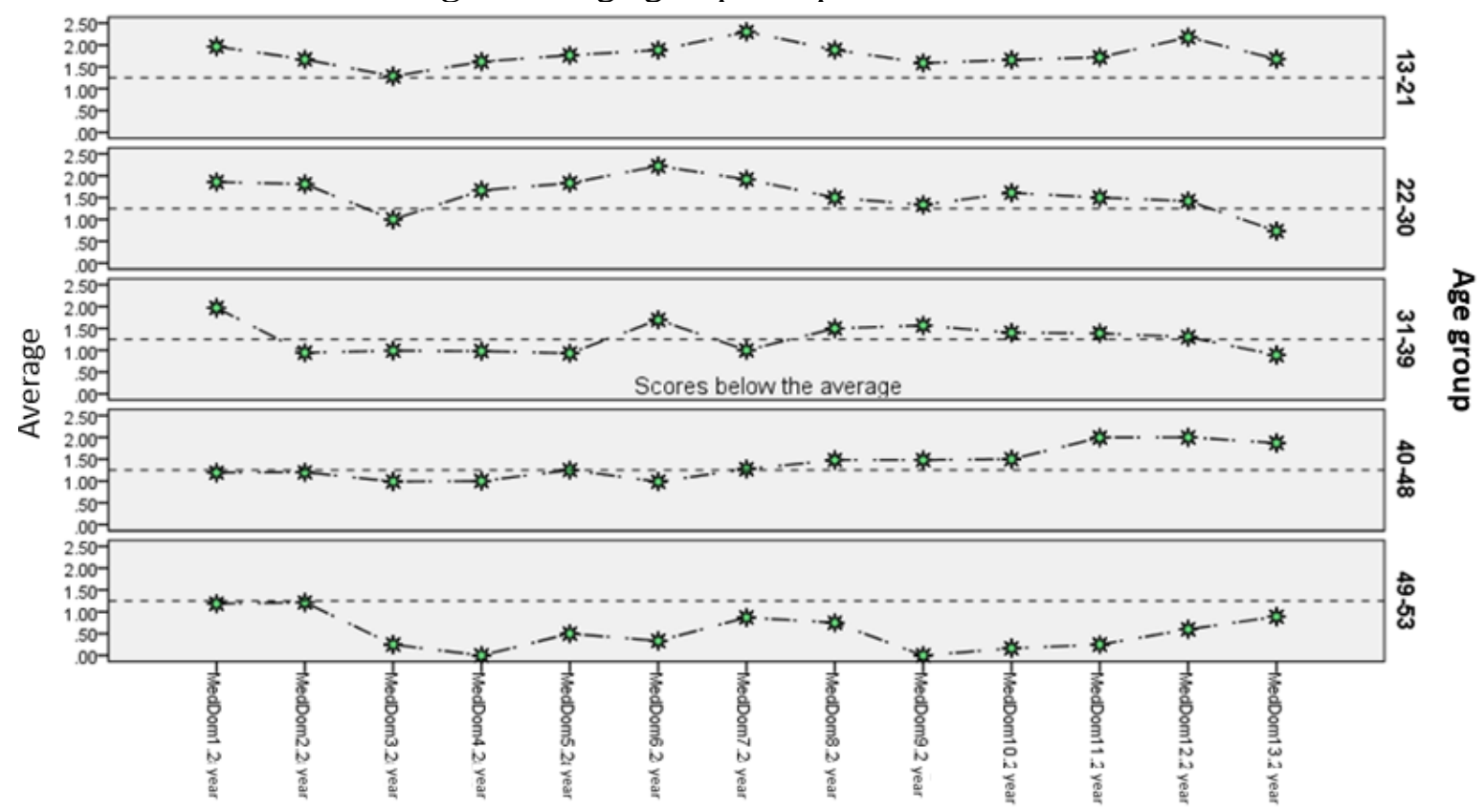

Source: elaborated by the author with the data from REBREDIG-PJA outcomes (2017)

First, population was divided in five groups, participants belonging to groups one (13 to 21 years) two (22 to 30 years) obtained the best scores in their knowledge about the use of technology at the beginning of the program.

At the same time, there is only one competence in which all age groups are below average (Copyright knowledge), related to: identifying copyright within any software, application or work, detecting when content is protected by copyright or licenses, knowing the consequences of downloading protected digital content from internet (music, movies. etcetera); knowing copyright and / or creative commons symbols.

Finally, results point toward the older the participant, fewer competences they have for technology usage, conduct observed at age group 5 (48 to 53 years), where none of the competences exceeds the average. 


\section{Pretest competence level by marital status}

Figure 2 contrasts the 13 digital competences by marital status of YP\&A participating in the study.

Figure 2. Marital status competences contrast.

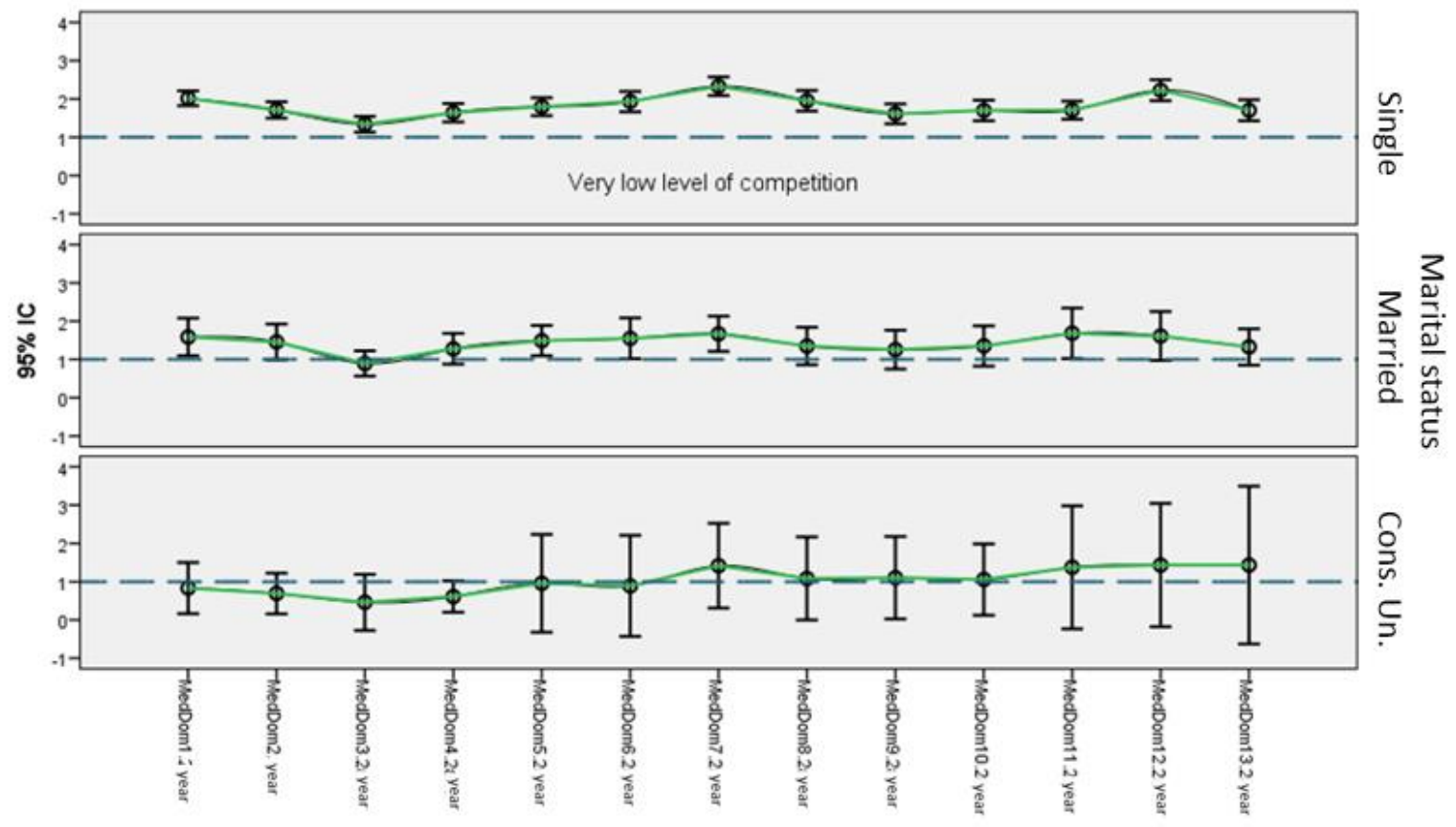

Source: elaborated by the author with the data from REBREDIG-PJA outcomes (2017)

To begin with, married people and those living on consensual union have lower levels of digital competence when compared to singles. This situation could reflect they spend less time on ICT's due to the responsibilities they face on daily basis in parallel with bachelors. In the same manner of age, Copyright knowledge is the competence with the lowest scores in all groups, indicating a generalizable deficiency for the entire population.

\section{Pre-test competence level by study degree}

Figure 3 highlights results for participant's study levels. As might be expected, partakers with elementary and middle school levels are close to the minimum proficiency boundary (dotted line), indicating these participators have weaker competences towards technology use.

As might be expected, the higher the study level, technological usage and knowledge improves, as illustrated in Figure 3, where participants with a high school diploma, obtained scores above the average line in the thirteen digital competences. 
Figure 3. Study level competences contrast.

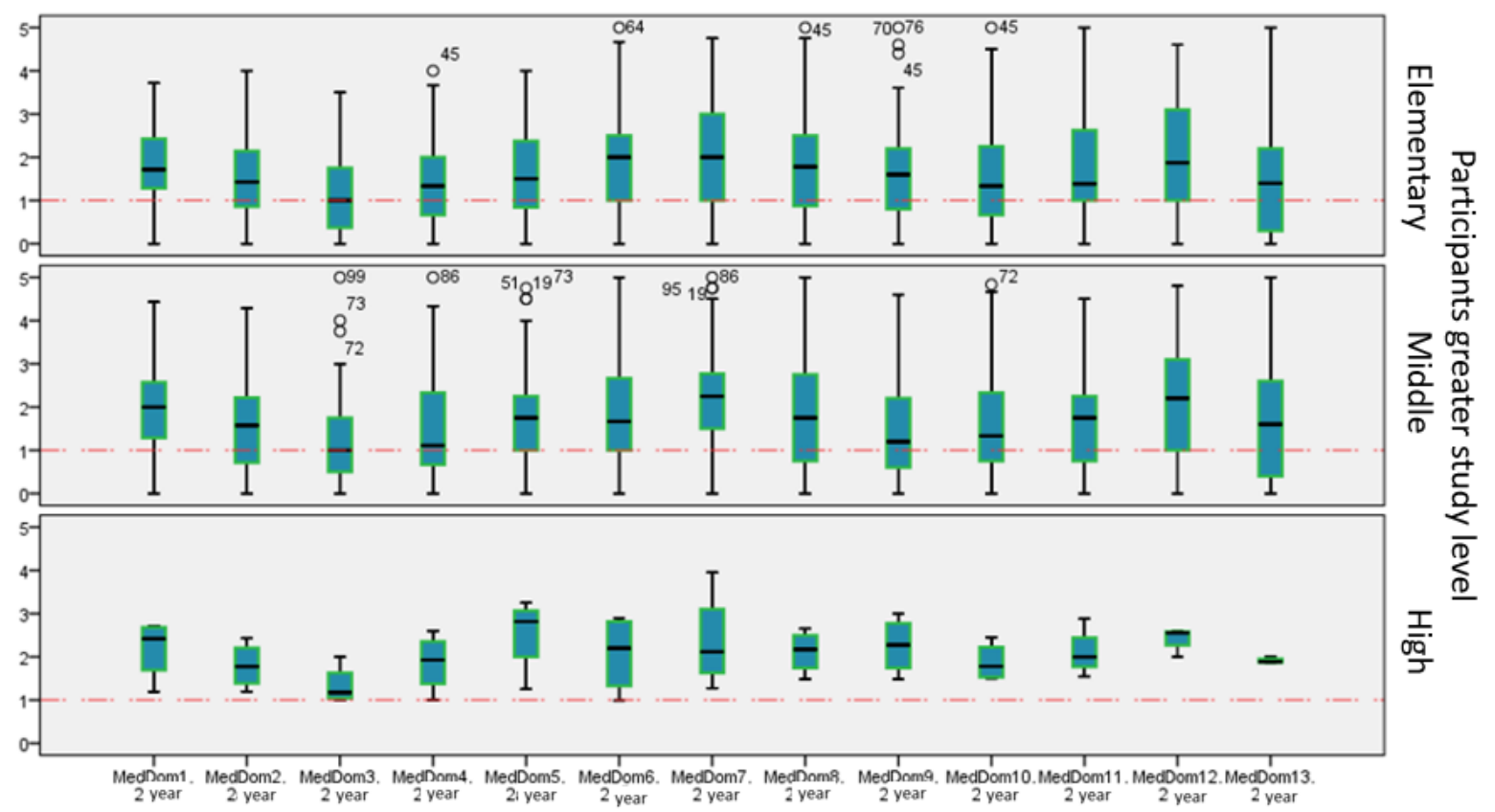

Source: elaborated by the author with the data from REBREDIG-PJA outcomes (2017)

In common with variables previously examined: sex, age and marital status, Copyright knowledge also obtained the lowest score, being the only domain where high school graduates average scores "grazed" the minimum competence line.

\section{Elements inhibiting digital divide reduction in Mayan-speaking communities}

As part of the methodology used in this work, training program participants were divided in two focus groups. Qualitative data analysis and interpretation was formulated using ATLAS.ti (version 8), a tool setting employed for qualitative analysis of large bodies of textual and graphic data from created hermeneutic units (HU). Data analysis process involved four stages: data preparation (collection and storage), initial analysis (open coding), main analysis (indexed system refinement) and results (key concepts, relationships and models). During open coding procedure, in the initial analysis stage, categories and subcategories came into sight, as presented in Figure 4 conceptual network. 
Figure 4. Conceptual network of elements inhibiting digital divide reduction.

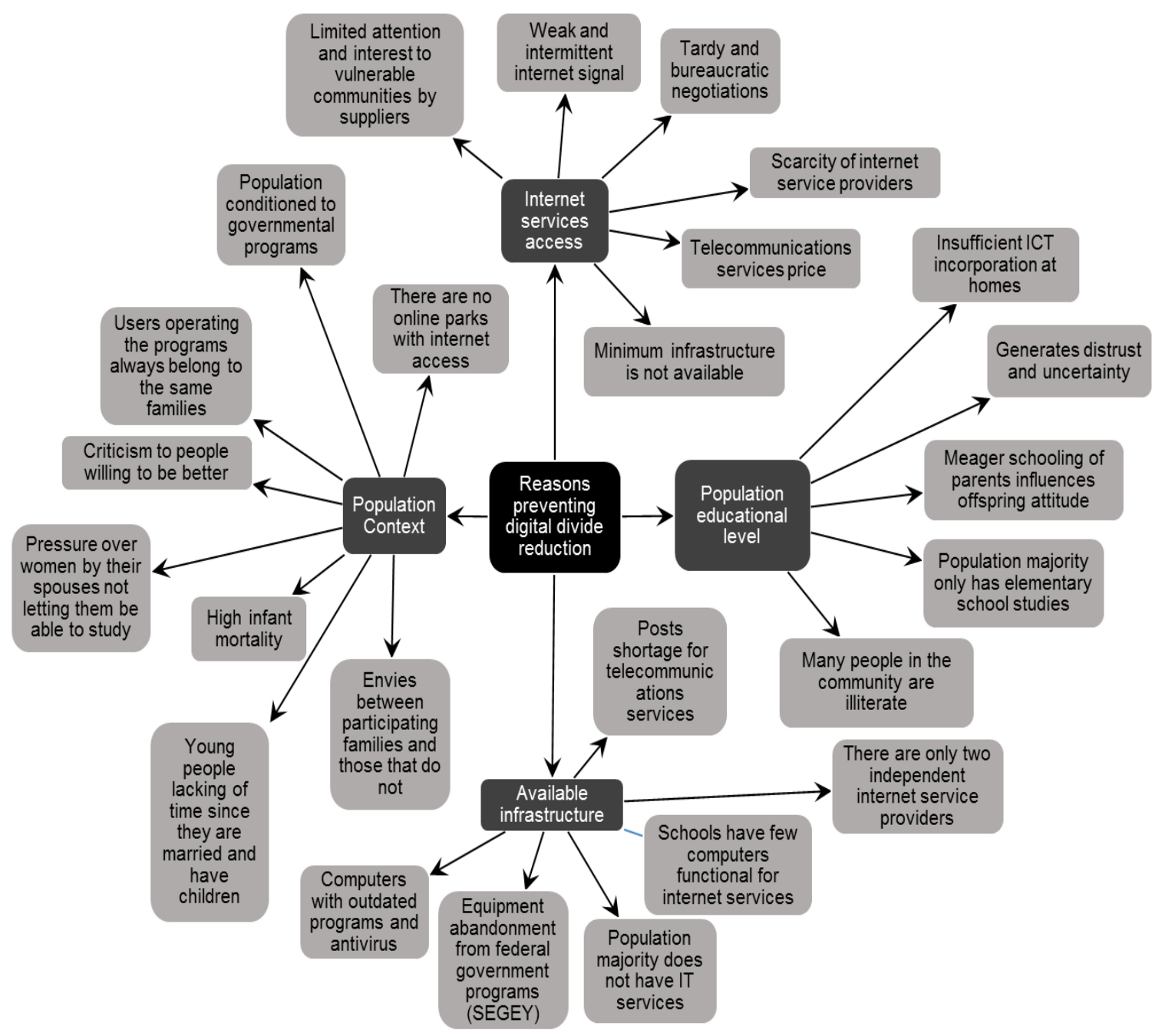

Source: elaborated by the author with data from focus group outcomes (2017)

Some of the most relevant elements inhibiting digital divide reduction integrating subcategories are the following:

- Difficult access to internet providers

- Poor infrastructure and facilities

- Difficulty leaving their homes and participating in program activities

- Unawareness on how to work online (platform)

- Non-Maya-speaking teachers clarify doubts in Spanish, not Maya

- Lack of time, due to house chores and children attention

- Few inhabited houses with internet access.

- Security deficiency on ICT management

- Technological resources use distrust 


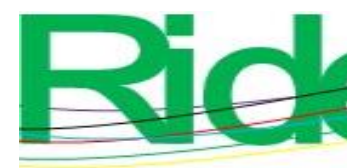

Revista Iberoamericana para la Investigación y el Desarrollo Educativo ISSN $2007-7467$

- ICT management fear and uncertainty

- People rumors to block others growth

- Envy

\section{Discussion}

Mexico's official dispositions on education (National Development Plan 2013-2018, National Digital Strategy, 2013) and for Yucatan State (State Development Plan, 2012-2018) propose states and municipalities to outline and incorporate strategies to increase educational quality in urban and rural areas from elementary to secondary level.

However, despite governmental guidelines and international recommendations prioritizing a more equitable distribution of educational opportunities amongst vulnerable regions and social and ethnic groups, with a gender perspective (OECD, 2017; CEPAL, 2019), reality shows there still are access, habilitation, academic training and technology usage and management differences between men and women, which increase opportunities gap for females by not joining knowledge society.

Literature suggests that digital technology has the potential to create connections, encourage learning, raise inclusion levels and even provide lifesaving information. Nevertheless, evidence worldwide reports differences amid countries, translated to indicators such as: educational level, economic stability, parents schooling, growth and development; factors that collaterally increase cost, coverage, access and digital literacy level barriers of the most vulnerable groups impeding the development of technology use advanced skills.

An important consideration of this study is that, notwithstanding men from a Maya-speaking community in Yucatan exhibited better technology use competence levels in variables such as maximum degree of studies, marital status and age. It seems that women, could reach better outcomes by narrowing this gap if they are promoted more, starting from within their families, allowing them to access higher education and employment levels, breaking cultural barriers, as machismo and domination, improving their living conditions. In their own words: "We make an effort to be here, in addition to complying with the activities of the program, we have to fulfill with the tasks of our home, which implies being aware of our spouses, taking care of our children, and take care of our family." 


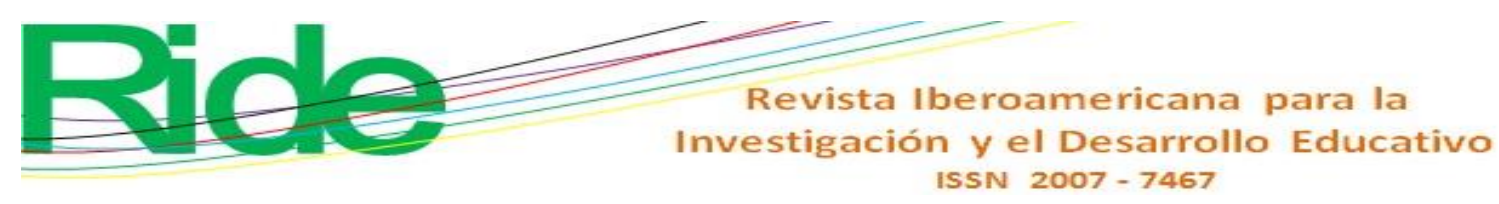

\section{Conclusion}

Gender digital divide phenomenon in Yucatan's vulnerable Maya-speaking communities has been little studied in Mexico and documented evidence from scientific studies is incipient. However, factors causing it, as well as its consequences, are tasks that require immediate attention for southeastern Mexico inhabitant's well-being. Access to computer equipment and technology and internet use enablement are some of the differences that affect women, broadening the inequality gap with men, sidestepping from knowledge society, as well as life and work increase and improvement conditions.

This article analyzed differences in technology use between men and women of the Mayaspeaking community of Mayapan, Yucatan through a diagnosis administered to 119 people prior to participating in a training program called: REBREDIG -PJA. Based on results examination, it can be concluded that Mayapan presents a gender digital divide, since men report better skills to use and access technology in comparison with women. A deeper analysis suggests that, even with the same level of education, men have better skills for the technology use than women do. If participants are grouped by marital status, single men demonstrated better skills for technology use compared to women in the same condition. Finally, age impact on digital competences development is relevant, concluding that at a younger age, the existing technologies use competence level is higher, considering younger partakers age ranges from 13 to 15 years old.

This paper seeks to initiate a dialogue about the importance of implementing actions to allow digital inclusion, regardless of gender, ethnicity, social class, physical condition or disability type; therefore, is essential to raise digital and technological use qualification in rural communities in southern Yucatan. As mentioned in State's Development Plan (2013-2018) 39 out of the 106 municipalities population (in average) has not finished elementary school ( $1^{\text {st }}$ to 6 st grade). In literacy terms, Mérida (state capital), presents the lowest percentage, while in southern and eastern municipalities, such as Mayapan, Tahdziu and Chemax, have percentages higher than $27 \%$ of the population.

This study findings reveal a pending work agenda for regional post-secondary institutions (Yucatan`s Autonomous University, Campeche's Autonomous University, Quintana Roo’s University, Chiapas` Autonomous University and Tabasco's Juarez Autonomous University) as well for state government ministries and agencies in charge of education and program development to attention vulnerable communities [Education Secretary of Yucatan State 


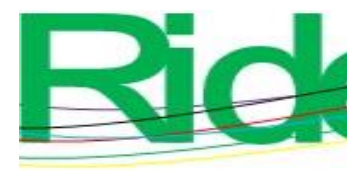

Revista Iberoamericana para la
Investigación y el Desarrollo Educativo
ISSN $2007-7467$

Government (SEGEY), Education Secretary of Campeche State Government (SEDUC), Education Secretary of Quintana Roo (SEQ), Education Secretary of Chiapas State, Education Secretary of Tabasco], validating this studies results by replicating it through the National Institute for Adult Education (INEA) and the National Commission for the Development of Indigenous Communities (INPI). Finally, this study contributes promoting educational innovation projects, which focus on life quality improvement for Yucatecan women, from vulnerable communities, while strengthens the state's accountability process to increase educational excellence.

\section{References}

Anderson, S. (2015). India's Gender Digital Divide: Women and Politics on Twitter. Observer Research Foundation ORF ISSUE BRIEF. October, N8, 108. New Delhi. Obtained from: https://www.orfonline.org/wpcontent/uploads/2015/12/ORFIssueBrief_108.pdf

Atkinson, J., Black, R., \& Curtis, A. (2008). Exploring the digital divide in an Australian Regional City: a case study of Albury. Australian Geographer, 39, 479-493. doi:10.1080/ 00049180802419203

Boggino, N. y Rosekrans, K. (2007). Investigación-acción: reflexión crítica sobre la práctica docente. Obtenido de: http://revistas.ufro.cl/ojs/index.php/educacion/article/view/860/734

British Council (2016). Gender equality and empowerment of women and girls in the UK. Obtained from: https://www.britishcouncil.org/sites/default/files/gender_equality_an_empowerment _in_the_uk.pdf

Castaño, C., Martín, J. y Martínez, J. (2011). La brecha digital de género en España y Europa: medición con indicadores compuestos. Revista Española de Investigaciones Sociológicas. pp. 127-140. Obtenido de: http://www.reis.cis.es/REIS/PDF/REIS_136_061318594338821.pdf

Comisión Económica para América Latina y el Caribe [CEPAL], (2019). Planes de igualdad de género en América Latina y el Caribe. Mapas de ruta para el desarrollo. Observatorio de Igualdad de Género en América Latina y el Caribe. Obtenido de: https://repositorio.cepal.org/bitstream/handle/11362/41014/6/S1801212_es.pdf

Cooper, J. (2006). The digital divide: The especial case of gender. Journal of Computer 


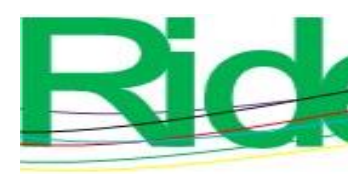

Revista Iberoamericana para la Investigación y el Desarrollo Educativo ISSN 2007 - 7467

Assisted Learning, 22,320-334. doi: 10.1111/j.1365-2729.2006.00185.x

Cooper, J. \& Weaver, K. D. (2003). Gender and computers: Understanding the digital divide. Mahwah, NJ: Lawrence Erlbaum. Obtained from: https://www.academia.edu/7175787/Gender_and_Computers_Understanding_the_D igital_Divide

Domínguez, G., P. Canto., J. Ortega y D. McCalman (2016). Raising the Technological Competence of High School Science and Mathematics Teachers of México through Delivery of an Online Program. International Journal of Technology, Policy and Management. Vol. 16 (2). Pp. 163-180. doi: 10.1504/IJTPM.2016.076317

Dominguez, J., Vazquez, I., Suaste, M., \& Cab, V. (2016). Reduccion de la brecha digital en PJA de comunidades vulnerables de Yucatan. [Digital divide reduction in PJA on vulnerable communities in Yucatan]. Research Project FCYA-2016-0001W. Mexico: K Kellogg Foundation

Domínguez, G. (2015). Desarrollo de competencias en el uso de las TIC en profesores de ciencias de secundaria. Tesis doctoral. Universidad de Granada. Obtenido de https://hera.ugr.es/tesisugr/25613376.pdf

Dionne-Simard, D., Galarneau, D., \& Larochelle-Coté, S. (2016). Woman in scientific occupations in Canada. Statistical Information Service. Canada. Obtained from: https://www.researchgate.net/publication/312307838_Women_in_scientific_occupa tions_in_Canada

Dixon, L.J., Correa, T., Straubhaar, J., Covarrubias, L., Graber, D., Spence, J., \& Rojas, V. (2014). Gendered Space: The Digital Divide between Male and Female Users in Internet Public Access Sites. Journal of Computer-Mediated Communication, 19, 991-1009. doi:10.1111/jcc4.12088

Economic Co-operation and Development: an international, (2001). Understanding the Digital Divide. Paris, France. Obtained: https://www.oecd.org/sti/1888451.pdf Economic Co-operation and Development: an international, (2013). Capturing Digital Dividends and Closing Digital Divides. Obtained from: http://www.oecd.org/governance/pcsd/Capturing\%20Digital\%20Divides.pdf Economic Co-operation and Development: an international, (2017). Education at a Glance 2017: OECD Indicators. Obtained from: https://doi.org/10.1787/eag-2017-en Elliot, J. (2005). El Cambio Educativo desde la Investigación Acción. (4aEd). Madrid: 


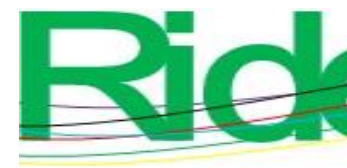

Revista Iberoamericana para la Investigación y el Desarrollo Educativo ISSN 2007 - 7467

Ediciones Morata

Eynon, R. (2009). Mapping the digital divide in Britain: implications for learning and education. Learning, media and technology, 34, 277-290. Obtained from: https://www.tandfonline.com/doi/abs/10.1080/17439880903345874

Ginsburg, L. Sabatini J. \& Wagner, D. (2000). Basic skills in Adult Education and the Digital Divide. Obtained from:

https://www.oecd.org/site/schoolingfortomorrowknowledgebase/themes/ict/412846 92.pdf

Gobierno de la República (2013). Estrategia Digital Nacional. Obtenido de: https://www.gob.mx/cms/uploads/attachment/file/17083/Estrategia_Digital_Nacion al.pdf

GSMA (2010). Women \& Mobile: A Global Opportunity. A Study on the Mobile Phone Gender Gap in Low- and Middle-income Countries. Obtained from https://gsdrc.org/document-library/women-mobile-a-global-opportunity-a-study-onthe-mobile-phone-gender-gap-in-low-and-middle-income-countries/

Gurumurthy, A., \& Chami, N. (2014). Gender equality in the information society: a review of current literature and recommendations for policy and practice. Obtained from https://www.researchgate.net/publication/297737616_Gender_equality_in_the_infor mation_society_a_review_of_current_literature_and_recommendations_for_policy_ and_practice

Instituto Nacional de Estadística y Geografía, (2010). Panorama sociodemográfico de Yucatán. Mexico. Obtenido de: http://coespo.yucatan.gob.mx/general/31_Panorama_Yuc.pdf

Inter-American Development Bank (2012). Bridging Gaps, Building Opportunity Broadband as a Catalyst of Economic Growth and Social Progress in Latin America and the Caribbean. Understanding the Digital Divide. OECD Publications, Paris: France. Obtained from: https://publications.iadb.org/en/publication/11729/bridginggaps-building-opportunity-broadband-catalyst-economic-growth-and-social

INE [Instituto Nacional de Estadistica], (2016). Anuario Estadistico de España. Obtenido de: https://www.ine.es/prodyser/pubweb/anuarios_mnu.htm

Integrated Electronics Corporation, (2013). Women and the Web: Bridging the Internet 


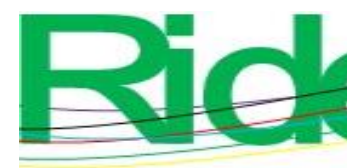

\section{Revista Iberoamericana para la Investigación y el Desarrollo Educativo ISSN 2007 - 7467}

Gap and Creating New Global Opportunities in Low and Middle-income Countries. Obtained from:

https://www.intel.com/content/dam/www/public/us/en/documents/pdf/women-andthe-web.pdf

Lichy, J. (2011). Internet use behaviour in France and Britain: exploring socio-spatial disparity among adolescents. International journal of consumer studies, 35, 470475. Obtained from: https://www.researchgate.net/publication/230271754_Internet_user_behaviour_in_F rance_and_Britain_Exploring_socio-spatial_disparity_among_adolescents

Livingstone, S. \& Helsper, E. (2007). Gradations in digital inclusion: children, young people and the digital divide. New media \& society, 9, 671-696. Obtained from: https://journals.sagepub.com/doi/10.1177/1461444807080335

National Center for Woman \& Information Technology [NCWIT], (2010). NCWIT Scorecard: A Report on the Status of Women in Information Technology. Obtained from: https://www.issuelab.org/resources/18105/18105.pdf

Negreiro, M. (2015). Bridging the digital divide in the EU. Members Research Service. Obtained from: https://www.europarl.europa.eu/RegData/etudes/BRIE/2015/573884/EPRS_BRI(20 15)573884_EN.pdf

Plan Estatal de Desarrollo (2012-2018). Gobierno del Estado. Mérida; Yucatan; Mexico. Obtenido de: http://www.yucatan.gob.mx/docs/transparencia/ped/2012_2018/PED_2012_2018.pd $\mathrm{f}$

Plan Nacional de Desarrollo (2013-2018). Gobierno de la República. Cd. de Mexico, Obtenido de: https://www.snieg.mx/contenidos/espanol/normatividad/MarcoJuridico/PND_20132018.pdf

Powell, C., \& Mei Chang, A. (2016). Woman in Tech as a Driver for Growth in Emerging Economies. Council on Foreign Relations. Obtained from: https://www.cfr.org/report/women-tech-driver-growth-emerging-economies

Schlelfe, K. (2008). Regional versus Individual Aspects of the Digital Divide Germany. 


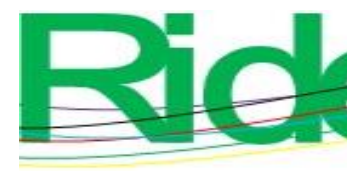

\section{Revista Iberoamericana para la Investigación y el Desarrollo Educativo ISSN $2007-7467$}

Centre for European Economic Research. Obtained from: ftp://ftp.zew.de/pub/zewdocs/dp/dp06085.pdf

Schinzel, B. (2017). Women in computing and the contingency of informatics cultures. Informatics in the future: proceedings of the 11th European Computer Science Summit (ECSS 2015). Obtained from https://link.springer.com/content/pdf/10.1007/978-3-319-55735-9_8.pdf

Servon, L. (2002). Bridging the Digital Divide. Technology, community and public policy. England: Blackwell Publishing. Obtained from: https://www.researchgate.net/publication/220175483_Bridging_the_Digital_Divide _Technology_Community_and_Public_Policy_by_Lisa_J_Servon_Oxford_Blackw ell_Publishing_2002_xix_273_pp_ISBN_0-631-23242-7

Suarez, J., Almerich, G., Gargallo, L., y Aliaga, F. (2010). Las competencias en TIC del profesorado y su relación con el uso de los recursos tecnológicos. Obtenido de: https://www.researchgate.net/publication/43768741_Las_competencias_en_TIC_de 1_profesorado_y_su_relacion_con_el_uso_de_los_recursos_tecnologicos

United Nations Educational Scientific and Cultural Organization, (2017). Leaving no one behind: from digital divide to digital empowerment. Obtained from: https://en.unesco.org/events/leaving-no-one-behind-digital-divide-digitalempowerment

Van Dijk J. \& Hacker, K. (2003). The digital divide as a complex and dynamic Phenomenon. The Information Society, 19, pp. 315-326. Obtained from: https://www.utwente.nl/en/bms/vandijk/research/digital_divide/Digital_Divide_over igen/pdf_digitaldivide_website.pdf

Vigneswara, P. (2013). The digital Divide in India. Inferences from the information and communication technology workforce. The internet and social inequality in international perspective. Obtained from:

https://www.researchgate.net/publication/282174833_The_digital_divide_in_India_ Inferences_from_the_information_and_communication_technology_workforce

Ward, K., Dragne, C., \& Lucas, A. (2014). Women in Computer Sciences in Romania: Success and Sacrifice. Journal of International Education and Leadership, 4, 1-23. Obtained from: https://files.eric.ed.gov/fulltext/EJ1135905.pdf

Women in Science, Technology and Engineering, (2015). The Talent Pipeline from 

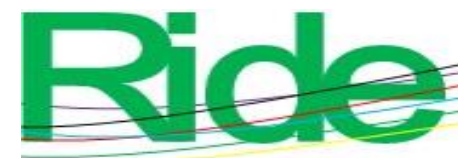

Classroom to Boardroom. UK: WISE Publishing. Obtained from:

https://www.wisecampaign.org.uk/wp-

content/uploads/2018/04/WISE_UK_Statistics_2014.pdf

World Bank, (2016). World Development Report 2016: Digital Dividends. Obtained from: https://books.google.com.mx/books?hl=es\&lr=\&id=dAl-

CwAAQBAJ\&oi=fnd\&pg=PP1\&dq=World+Bank,+(2016).+World+Development+ Report+2016:+Digital+Dividends\&ots=E5bXvdd7eA\&sig=CgU34F3ENTuLYRIW NzezzW7u_rE

World Economic Forum (2013). The Global Information Technology Report. Growth and Jobs in a Hyperconnected World. Obtained from: http://www3.weforum.org/docs/WEF_GITR_Report_2013.pdf 


\begin{tabular}{|c|c|}
\hline Rol de Contribución & Autor (es) \\
\hline Conceptualización & J. Gabriel Dominguez Castillo «principal» \\
\hline Metodología & J. Gabriel Dominguez Castillo «principal» \\
\hline Software & $\begin{array}{l}\text { J. Gabriel Dominguez Castillo «principal», y Valentín Alonso } \\
\text { Novelo «que apoya». }\end{array}$ \\
\hline Validación & J. Gabriel Dominguez Castillo «principal» \\
\hline Análisis Formal & J. Gabriel Dominguez Castillo «principal» \\
\hline Investigación & J. Gabriel Dominguez Castillo «principal» \\
\hline Recursos & $\begin{array}{l}\text { J. Gabriel Dominguez Castillo «principal», y Valentín Alonso } \\
\text { Novelo «que apoya». }\end{array}$ \\
\hline Curación de datos & $\begin{array}{l}\text { Valentín Alonso Novelo «principal» y Sergio Humberto } \\
\text { Quiñonez Pech «que apoya». }\end{array}$ \\
\hline $\begin{array}{l}\text { Escritura - Preparación del } \\
\text { borrador original }\end{array}$ & $\begin{array}{l}\text { J. Gabriel Dominguez Castillo «principal», y Valentín Alonso } \\
\text { Novelo «que apoya». }\end{array}$ \\
\hline $\begin{array}{l}\text { Escritura - Revisión y } \\
\text { edición }\end{array}$ & $\begin{array}{l}\text { Valentín Alonso Novelo «principal»y Sergio Humberto } \\
\text { Quiñonez Pech «que apoya». }\end{array}$ \\
\hline Visualización & $\begin{array}{l}\text { Valentín Alonso Novelo «principal» y Sergio Humberto } \\
\text { Quiñonez Pech «que apoya». }\end{array}$ \\
\hline Supervisión & J. Gabriel Dominguez Castillo «principal» \\
\hline $\begin{array}{l}\text { Administración de } \\
\text { Proyectos }\end{array}$ & J. Gabriel Dominguez Castillo «principal» \\
\hline Adquisición de fondos & $\begin{array}{l}\text { J. Gabriel Dominguez Castillo,, Valentín Alonso Novelo, } \\
\text { Sergio Humberto Quiñonez Pech «igual» }\end{array}$ \\
\hline
\end{tabular}

